University of Nebraska - Lincoln

DigitalCommons@University of Nebraska - Lincoln

Faculty Publications: Department of Entomology

Entomology, Department of

1998

Sunflower Resistance to the Red Sunflower Seed Weevil

(Coleoptera: Curculionidae)

Huihua Gao

North Dakota State University

Gary J. Brewer

University of Nebraska-Lincoln, gbrewer2@unl.edu

Follow this and additional works at: https://digitalcommons.unl.edu/entomologyfacpub

Part of the Entomology Commons

Gao, Huihua and Brewer, Gary J., "Sunflower Resistance to the Red Sunflower Seed Weevil (Coleoptera: Curculionidae)" (1998). Faculty Publications: Department of Entomology. 224.

https://digitalcommons.unl.edu/entomologyfacpub/224

This Article is brought to you for free and open access by the Entomology, Department of at DigitalCommons@University of Nebraska - Lincoln. It has been accepted for inclusion in Faculty Publications: Department of Entomology by an authorized administrator of DigitalCommons@University of Nebraska - Lincoln. 


\title{
Sunflower Resistance to the Red Sunflower Seed Weevil (Coleoptera: Curculionidae)
}

\author{
HUIHUA GAO AND GARY J. BREWER
}

Department of Entomalogy, North Dakota State University, Fargo, ND 58105

\begin{abstract}
J. Econ. Entomol. 91(3): 779-783 (1998)
ABSTRACT The red sunflower seed weevil, Smicronyx fulvus LeConte (Coleoptera: Curculionidae), is a major insect pest of sunflower in North Dakota, South Dakota, and Minnesota. Economic damage is caused by the larvae which are internal seed feeders. During the 1992-1995 growing seasons, sunflower accessions were artificially infested and evaluated for resistance to the red sunflower seed weevil. Accessions 170411, 253417, and 170424 were resistant to the red sunflower seed weevil. Morphological types within accessions 170411 and 170424 varied for seed and pollen color and resistance to the red sunflower seed weevil. The resistant variant of accession 170424 had $45 \%$ of the seed damage of the susceptible type. In accession 170411, damage in the resistant type was $55 \%$ of the susceptible. Antixenosis was the major resistance mechanism detected in accessions 170411 and 170424
\end{abstract}

KEY WORDS Smicronyx fulvus, Helianthus annutus, host plant resistance, antixenosis

ThE RED Sunflower seed weevil, Smicronyx fulvus LeConte, can cause serious economic damage to cultivated sunflower, Helianthus annuus L. (Charlet et al. 1987), and in North Dakota, South Dakota, and Minnesota, it is a key insect pest. The red sunflower seed weevil is attracted to sunflower at the pollen shed stage as a food source and oviposition site. Larvae are internal feeders in single seeds and when mature, escape the seeds by chewing an exit hole in the seed and dropping to the soil (Brewer 1991).

Although planting dates (Oseto et al. 1987) and trap cropping (Brewer and Schnidt 1995) can be used to manage the red sunflower seed weevil, most farmers use chemical controls (McMullen et al. 1990). However, chemical controls are not always satisfactory; they are expensive, and application can adversely affect pollinating insects (Rogers and Kneitner 1983). Thus, the use of sunflower varieties resistant to the red sunflower seed weevil is desirable. The goal of this study was to identify red sunflower seed weevil resistance in sunflower accessions and to determine the mechanisms of resistance.

\section{Materials and Methods}

The Red Sunflower Seed Weevil. Adult weevils used in artificial infestation studies were collected from sunflower near Kindred, Cass County, ND. Other trials required newly emerged, unfed weevils. These weevil adults were reared from field-collected larvae using a method modified from Brewer (1992). Mature larvae dropping from sunflower heads in mid-October were collected and placed in sterile soil in plastic containers. The containers were covered and kept in cold storage $\left(4-5^{\circ} \mathrm{C}\right)$ for $\approx 90 \mathrm{~d}$ to break diapause and were then moved to a warm room $\left(31 \pm 0.5^{\circ} \mathrm{C}\right.$ with a photoperiod of 16:8 [L:D]). Emerging adults were collected every $2 \mathrm{~d}$ beginning approximately $75 \mathrm{~d}$ after the containers were moved to the warm room. Water was added to the containers as needed to keep the soil moist.

Germplasm Sources. Sunflower accessions were obtained from the USDA-ARS Plant Introduction Station at Ames, IA.

Germplasm Screening. In early June of 1992, 1993, and 1994, 10 sunflower accessions (Table 1) were planted at Prosper, Cass County, ND. A randomized complete block design with 4 blocks was used. Hybrid ' 894 ' was used as a standard check. Each accession was planted in a 5-m row with $76 \mathrm{~cm}$ between rows. Test rows alternated with rows planted to buffer hybrid

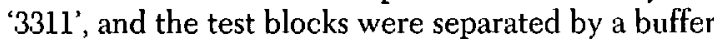
block of hybrid 3311. At the 6-leaf stage, seedlings were thinned to a plant spacing of approximately 25 $\mathrm{cm}$ so that there were $\approx 20$ plants in each row.

In 1995, accessions 170424 and 170411 (considered resistant based on previous years' results) and susceptible accessions 294658,431506 , and hybrid 894 were tested. However, hybrid 894 was not evaluated because the heads were damaged by an infestation of sunflower midge. In previous years' tests, we noted that seeds of accessions 170424 and 170411 had types that varied for seed or pollen color and that red sunflower seed weevil resistance seemed to vary with color type. The 1995 trial was done to test the relationship between resistance and color. Because of a limited number of seeds and poor germination in accessions 170424 and 1704ll, the seeds were germinated in the lab and transplanted to Jiffypots (Jiffy, Shippegan, Canada) in the greenhouse. At the 4-leaf 
Table 1. Three-year (1992, 1993, and 1994) means for number of damaged seeds per sunflower head resulting from artificial infestation with $S$. fulvus adults

\begin{tabular}{lcc}
\hline $\begin{array}{l}\text { Accession } \\
\text { or hybrid }\end{array}$ & $n$ & Damaged seeds \pm SEM \\
\hline 431506 & 10 & $72.4 \pm 25.91 \mathrm{a}$ \\
Hybrid 894 & 10 & $66.6 \pm 27.83 \mathrm{ab}$ \\
294658 & 10 & $63.1 \pm 34.67 \mathrm{ab}$ \\
175730 & 10 & $58.1 \pm 28.28 \mathrm{ab}$ \\
297475 & 10 & $53.1 \pm 22.61 \mathrm{abc}$ \\
343793 & 10 & $45.4 \pm 21.90 \mathrm{bcd}$ \\
170417 & 9 & $44.6 \pm 15.29 \mathrm{bcde}$ \\
480471 & 8 & $31.8 \pm 14.58 \mathrm{cde}$ \\
170424 & 9 & $22.9 \pm 13.07 \mathrm{de}$ \\
253417 & 9 & $22.1 \pm 8.84 \mathrm{e}$ \\
170411 & 8 & $21.9 \pm 9.18 \mathrm{e}$ \\
\hline
\end{tabular}

Means within the columns followed by the same letters are not significantly different ( $P>0.05$, Waller-Duncan $K$ ratio $t$-test) (SAS Institute 1985).

stage, they were transferred to the field. Each row had 13 plants with a spacing of $25 \mathrm{~cm}$ between plants and $76 \mathrm{~cm}$ between rows.

In each of the $4 \mathrm{yr}$ of the germplasm screening trials, a lepidopteran-specific insecticide (Bacillus thuringiensis Berliner) was used to prevent banded sunflower moth, Cochylis hospes Walsingham, infestation at the bud and early bloom stages of the sunflower plants. As individual sunflower plants reached stage R5.4-R.56 (40-60\% of the head with open florets, Schneiter and Miller (1981)), 2 plants per accession in each block were selected and infested with 30 red sunflower seed weevils. The infested sunflower heads were enclosed with Delnet pollination bags to prevent the weevils from escaping. Three days later, the artificially infested heads were uncovered and sprayed with malathion to kill the adults. In late August of each year, bags were placed on the selected sunflower heads to prevent bird damage and the loss of mature seeds. In early October, the artificially infested heads were harvested and dried. Once dry, they were threshed, and the number of larval damaged seeds per head was determined by counting the exit holes and larvae remaining within the seeds. Seeds were dissected to determine if larvae remained inside.

Antibiosis. In 1994, 2 additional heads per block of accessions 253417 and 170411 (resistant), 480471 (intermediate), and 294658, 431506, and hybrid 894 (susceptible) were selected from the germplasm screening trial. At plant stage R5.4-R5.6, the heads were artificially infested with weevils as described earlier. One half of each sunflower head was excised $5 \mathrm{~d}$ later. Each seed on the excised portion of the head was examined for red sunflower seed weevil eggs. The remaining half of the sunflower head was allowed to continue developing in the field and was harvested in late September. Preliminary trials showed that removing half the sunflower head did not affect seed development in the remaining half. The seeds were dehulled, and the number of larval damaged seeds was counted. Because larvae feed in only 1 seed, the number of larval damaged seeds was used as a measure of larval numbers. For each head tested, immature mor- tality was estimated by the formula: [ (number of eggs - number of damaged seeds) / number of eggs] $\times 100$. Previous tests showed that oviposition did not differ significantly between 2 sides of a head (H.G. unpublished data).

Antixenosis. Resistant accessions 170424 with white seeds and 170411 with seeds with yellow pollen and susceptible accessions 431506 and 294658 were used in 3 experiments: oviposition deterrent test 1 , oviposition deterrent test 2 , and a no-choice test for adult feeding preference. Oviposition deterrent tests 1 and 2 were conducted in the greenhouse using a completely randomized design to study the effects of resistant accessions on red sunflower seed weevil oviposition. Plants were grown in Sunshine mix number 1 (Fisons, Bellevue, WA) and fertilized with a soluble fertilizer (20-19-18) (Peters Professional, Peat-like Special, Fogelsville, PA) and iron chelate micronutrient (Sprint 330, Ciba, Greensboro, NC) using recommended rates. Greenhouse conditions were maintained at $\approx 22 \pm 5^{\circ} \mathrm{C}$ and a photoperiod of $16: 8$ (L:D) h. The plants were kept free of greenhouse insect pests. Artificial infestation was done as in earlier tests. Each accession was replicated 3-7 times, depending on seed availability.

Oviposition Deterrent Test 1 . Newly eclosed red sunflower seed weevils were conditioned by allowing them to feed for $7 \mathrm{~d}$ on plants of hybrid 894 that were shedding pollen. After conditioning, the weevils were used to infest artificially the test accessions. Three days later, the sunflower heads were dissected, and the totals for number of eggs per head were counted.

Oviposition Deterrent Test 2. A 2nd set of newly eclosed adults was conditioned separately on each of the test accessions ( 170411 yellow pollen, 170424 white seeds, 294658, and 431506) for $7 \mathrm{~d}$ during the pollen shed stage of plants. After conditioning, 3-7 heads of hybrid 894 were artificially infested with adults from each test accession. Three days later, seeds from the infested heads were dissected to determine oviposition per head.

No-Choice Test for Adult Feeding Preference. At plant stage R5.4-R5.6 (susceptible to oviposition, Brewer 1991), 2 additional plants per accession and block were selected from the 1995 germplasm screening trial and artificially infested as described earlier. Weevils were collected from a commercial sunflower field. Before artificially infesting the plants, they were examined for a natural weevil population, but no weevils were found. Three days after artificial infestation, the weevils were killed by spraying the heads with malathion. At day five, 20 seeds per selected head were randomly sampled, and the number of feeding-puncture scars per seed was checked under a microscope. Red sunflower seed weevils chew puncture holes in the seeds which serve as oviposition sites and can be used to measure oviposition preference (Brewer and Charlet 1995). Brewer and Charlet (1995) found that a randomly selected, 20-seed sample can accurately estimate the percentage of feeding-puncture scars per head. 
Table 2. Mean \pm SEM number of damnged seeds per hend in different sunflower accessions and color types within accessions in 1995 after artificial infestation with $S$. fulvus adults

\begin{tabular}{lrcrc}
\hline PI no. & $\begin{array}{c}\text { Seed } \\
\text { color }\end{array}$ & $\begin{array}{c}\text { Pollen } \\
\text { color }\end{array}$ & $n$ & Damaged seeds \\
\hline 170424 & B & Y & 10 & $156.9 \pm 98.76 \mathrm{a}$ \\
431506 & B & Y & 5 & $138.0 \pm 16.64 \mathrm{ab}$ \\
294658 & B & Y & 5 & $106.6 \pm 25.12 \mathrm{abc}$ \\
170411 & WS & D & 8 & $92.6 \pm 25.26 \mathrm{bc}$ \\
170424 & W & Y & 11 & $69.7 \pm 15.78 \mathrm{c}$ \\
170411 & WS & Y & 4 & $51.0 \pm 17.34 \mathrm{c}$ \\
\hline
\end{tabular}

Seed colors are coded as: $B$, black; $W$, white; and WS, white stripes Pollen colors are coded as $\mathbf{Y}$, yellow or $\mathrm{D}$, dark (dark purple, appearing black). Means within the column followed by the same letters are not significantly different ( $P>0.05$, Waller-Duncan $K$ ratio $t$-test) (SAS Institute 1985).

Data Analysis. Analysis of variance was performed using the general linear models procedure, and means were separated with the Waller-Duncan $K$ ratio $t$-test (SAS institute 1985).

\section{Results and Discussion}

Germplasm screening. Analysis of our 3-yr study showed that the number of damaged seeds per head differed significantly ( $F=8.05 ; \mathrm{df}=10,62 ; P=0.0001$ ) among accessions. Accessions 431506, 294658, 175730, and 297475 and hybrid 894 had significantly more damaged seeds per sunflower head than accessions 170411, 253417, and 170424 (Table 1). Thus, over the 3-yr period, the 1st group was susceptible and the later group was resistant to the red sunflower seed weevil. Accessions 343793,170417 , and 480471 were intermediate in response.

Seed and pollen color varied within some tested accessions, and the different color types within some accessions varied in resistance to the red sunflower seed weevil ( $F=3.66$; $\mathrm{df}=8,34 ; P=0.0036)$. Accession 170424 with black seeds had a mean of 156.9 damaged seeds per head, but the white-seeded type of the same accession had just 69.7 damaged seeds per head and differed significantly from the black-seeded type (Table 2). Seed color is determined by the presence or absence of pigment in each of 3 different seed coat layers (Putt 1940). White-colored seeds result from a lack of pigment in all 3 layers and are controlled by a dominant gene (Leclercq 1979). We do not know the inheritance of seed color in accession 170424, but both black or white seeds gave rise to plants that differed in seed color. Thus, seed color is segregating in the accessions, but resistance was consistently found in the white seeds. This may suggest that gene(s) controlling white color and resistance are linked. Further research needs to be done to test whether the red sunflower seed weevil resistance and white seed color are linked.

Antibiosis. The mean number of eggs per half-head differed significantly between resistant accessions and susceptible accessions $(F=4.26 ; \mathrm{df}=8,23 ; P=$ 0.0029 ). Seed weevil susceptible accession 294658 and hybrid 894 had significantly more eggs than the inter-
Table 3. Mean \pm SEM number of $S$. fulvus egga and larvae per half sunflower head in different sunflower accessions in 1994 after artificial infestation

\begin{tabular}{lccc}
\hline \hline $\begin{array}{c}\text { Accession or } \\
\text { hybrid }\end{array}$ & $N$ & Eggs & Larvae \\
\hline Hybrid 894 (S) & 7 & $83.8 \pm 11.17 \mathrm{a}$ & $82.7 \pm 15.03 \mathrm{a}$ \\
294658 (S) & 7 & $68.4 \pm 19.27 \mathrm{a}$ & $62.7 \pm 21.25 \mathrm{~b}$ \\
431506 (S) & 6 & $61.6 \pm 20.93 \mathrm{ab}$ & $57.3 \pm 14.96 \mathrm{bc}$ \\
$480471($ I) & 4 & $42.0 \pm 11.63 \mathrm{bc}$ & $39.0 \pm 6.87 \mathrm{~cd}$ \\
$253417(\mathrm{R})$ & 5 & $39.0 \pm 14.40 \mathrm{bc}$ & $31.4 \pm 10.99 \mathrm{~d}$ \\
$170411(\mathrm{R})^{a}$ & 3 & $29.3 \pm 30.98 \mathrm{c}$ & $24.6 \pm 14.87 \mathrm{~d}$ \\
\hline
\end{tabular}

S, susceptible; I, intermediate; and $\mathbf{R}$, resistant to red sunflower seed weevil (see Table 1 ). Means within the columns followed by the same letters are not significantly different $(P>0.05$, Waller-Duncan $\mathbf{K}$ ratio $t$-test) (SAS Institute 1985).

${ }^{a}$ Resistant color type of accession 170411 with yellow pollen (see Table 2).

mediate (480471) and resistant (253417 and 170411) accessions (Table 3). The mean number of larvae per half-head also differed significantly among the accessions tested ( $F=7.33 ; \mathrm{df}=8,23 ; P=0.0001$ ). The susceptible accessions 294658 and 431506 and hybrid 894 had significantly more larvae than the resistant accessions 253417 and 170411 (Table 3). There was no significant difference in immature mortality among the accessions tested ( $F=0.64 ; \mathrm{df}=8,23 ; P=0.7338$ ). Therefore, we did not find antibiosis in the resistant accessions we tested, although Brewer and Charlet (1995) found a low level of antibiosis to the red sunflower seed weevil in a different set of accessions.

Antixenosis. After newly eclosed red sunflower seed weevils were conditioned on susceptible hybrid 894 for $7 \mathrm{~d}$, they oviposited significantly fewer eggs on the resistant accessions than on the susceptible accession $(F=4.72 ; \mathrm{df}=2,12 ; P=0.0236)$. Accession 431506 had more than twice as many eggs per head (111.6) as accession 170424 with white seeds (42.6) and accession 170411 with yellow pollen (27.2) (Table 4). Newly emerged red sunflower seed weevil females need to feed on pollen and other sunflower tissues to develop eggs (Rana 1995). Because we started with newly eclosed weevils and the weevils were conditioned for $7 \mathrm{~d}$ on hybrid 894 before transferring them to the test accessions, they all should have had equivalent egg-laying capacity. Thus, the significantly fewer number of eggs found on the resistant accessions (170424 and 170411) suggests that those accessions inhibited or deterred red sunflower seed weevil oviposition. A similar phenomenon occurs in other resistant plants, such as Peruvian maize which reduces European corn borer, Ostrinia nubilalis (Hubner), oviposition (Abel et al. 1995).

In the reciprocal test, newly eclosed weevils were conditioned by feeding on resistant (170411 and 170424) and susceptible (431506 and 294658) accessions for $7 \mathrm{~d}$. Weevils from the different conditioning hosts oviposited significantly different numbers of eggs when transferred to hybrid 894 ( $F=11.47$; $\mathrm{df}=$ $3,17 ; P=0.0002)$. Interestingly, weevils conditioned on resistant accession 170411 (white-striped seeds) oviposited significantly more eggs (129.0) than wee- 
Table 4. Mean \pm SEM nunber of S. fulvus eggs on oviposition hosts after feeding on a conditioning host for $7 \mathrm{~d}$ in 1995

\begin{tabular}{|c|c|c|c|}
\hline $\begin{array}{c}\text { Conditioning } \\
\text { host }^{a, b}\end{array}$ & $\begin{array}{l}\text { Oviposition } \\
\text { host }^{b}\end{array}$ & $N$ & Eggs \\
\hline \multicolumn{4}{|c|}{ Oviposition deterrent test 1} \\
\hline $\begin{array}{l}\text { Hybrid } 894 \text { (S) } \\
\text { Hybrid } 894 \text { (S) } \\
\text { Hybrid } 894 \text { (S) }\end{array}$ & $\begin{array}{l}431506(\mathrm{~S}) \\
170424(\mathrm{R}) \\
170411(\mathrm{R})\end{array}$ & $\begin{array}{l}5 \\
6 \\
4\end{array}$ & $\begin{aligned} 111.6 & \pm 60.27 a \\
42.6 & \pm 12.33 b \\
27.2 & \pm 8.18 b\end{aligned}$ \\
\hline \multicolumn{4}{|c|}{ Oviposition deterrent test 2} \\
\hline $170411(\mathrm{R})$ & $\begin{array}{l}\text { Hybrid } 894 \\
\text { (S) }\end{array}$ & 3 & $129.0 \pm 8.71 \mathrm{a}$ \\
\hline $170424(\mathrm{R})$ & $\begin{array}{l}\text { Hybrid } 894 \\
\text { (S) }\end{array}$ & 5 & $102.0 \pm 32.03 \mathrm{~b}$ \\
\hline $294658(\mathrm{~S})$ & $\begin{array}{l}\text { Hybrid } 894 \\
\text { (S) }\end{array}$ & 6 & $78.0 \pm 15.46 b c$ \\
\hline $431506(S)$ & $\begin{array}{l}\text { Hybrid } 894 \\
\text { (S) }\end{array}$ & 7 & $53.5 \pm 16.54 c$ \\
\hline
\end{tabular}

Within a test, mean number of eggs followed by the same letters are not significantly different ( $P>0.05$, Waller-Duncan $\mathrm{K}$ ratio $t$-test) (SAS Institute 1985).

a Sunflower germ plasm used to condition newly eclosed weevils for $7 \mathrm{~d}$ before being transferred to an oviposition host.

${ }^{b}$ Hybrid 894 and accessions 294658 and 431506 are susceptible (S) to red sunflower seed weevil. Accessions 170424 (white seeds) and 170411 (yellow pollen) are red sunflower seed weevil-resistant (R) color types (see Table 2).

vils conditioned on susceptible accession 431506 (53.5) (Table 4). Korman and Oseto (1989) found that the red sunflower seed weevil requires $5 \mathrm{~d}$ of pollen feeding to complete oocyte development. Rana (1995) found that newly eclosed red sunflower seed weevil can begin ovipositing after 4 days of feeding on floral tissues. It is probable that the female adults developed eggs during the 7-d conditioning period, regardless of which accession was host, but if they were on a resistant accession they did not oviposit their eggs because of oviposition antixenosis. Then when the weevils were transferred to susceptible hybrid 894, they had a large number of eggs ready for oviposition. The opposite may have occurred when the weevils were conditioned on susceptible accession 431506 and to a lesser extent on 294658. They developed eggs and oviposited some of them during the 7-d conditioning period so that when they were transferred to hybrid 894 , fewer eggs were available for oviposition.

Puncture scars per achene were significantly higher in susceptible accession 431506 (1.8) than in the other accessions tested $(F=3.87 ; \mathrm{df}=6,9 ; P=0.0343$ ) (Table 5). This supports earlier evidence that accessions 170411 and 170424 are antixenotic. Brewer and Charlet (1995) detected antixenosis in a number of sunflower accessions. They found that the number of scars per pericarp was significantly correlated with the percentage of seed with larvae and with inclusive damage which included seeds damaged by emerged and successfully developed larvae and unemerged larvae remaining in the seed.

Our studies demonstrate that resistance to the red sunflower seed weevil, in the form of antixenosis, is present in some of the sunflower accessions tested. Identification of accessions resistant to the red sun-
Table 5. Mean \pm SEM number of $S$. filvus adult puncture scars per achene in different sunflower accessions

\begin{tabular}{lcc}
\hline \hline Accession no. & & \\
\hline $431506(\mathrm{~S})$ & $N$ & Puncture scars per seed \\
294658 (S) & 4 & $1.8 \pm 0.40 \mathrm{a}$ \\
170424 (R) & 4 & $1.0 \pm 0.37 \mathrm{~b}$ \\
170411 (R) & 4 & $0.8 \pm 0.31 \mathrm{~b}$ \\
\end{tabular}

Mean number of puncture scurs per seed followed by the same letters are not significantly different $(P>0.05$, Waller-Duncan K ratio $t$-test) (SAS Institute 1985).

"Accessions 294658 and 431506 , susceptible to red sunflower seed weevil. Accessions 170424 (white seeds) and 170411 (yellow pollen) red sunflower seed weevil-resistant color types (see Table 2).

flower seed weevil will be useful for developing commercial hybrids with red sunflower seed weevil resistance. Because the resistance was maintained in nochoice situations, the need for insecticidal controls in hybrids developed from these accessions should be reduced.

Within an accession there may be 2 or more different pollen or seed colors, and resistance was sometimes associated with a specific color (e.g., whitecolored seeds in accession 170424). It is not known how color and resistance are related, but genetic tests should be conducted to determine whether a linkage exists between genes for color and resistance. Synthesis of inbred lines to stabilize the genetic background within resistant accessions should be a priority in further research.

\section{Acknowledgments}

We thank Warren G. Schmidt for assistance with field work. This research was supported in part by USDA grant 58-3625-1-102.

\section{References Cited}

Abel, C. A., R. L. Wilson, and J. C. Robbins. 1995. Evaluation of Peruvian maize for resistance to European corn borer (Lepidoptera: Pyralidae) leaf feeding and ovipositional preference. J. Econ. Entomol. 88: 1044-1048.

Brewer, G. J. 1991. Oviposition and larval bionomics of two weevils (Coleoptera: Curculionidae) on sunflower. Ann. Entomol. Soc. Am. 84: 67-71.

Brewer, G. J., and L. D. Charlet. 1995. Mechanisms of resistance to the red sunflower seed weevil in sunflower accessions. Crop Prot. 14: 501-503.

Brewer, G. J., and G. Schmidt. 1995. Trap cropping to manage the red sunflower seed weevil in oilseed sunflower. Am. J. Altern. Agric. 10: 184-197.

Brewer, L. N. 1992. Development of methods for large scale production of adult sunflower seed weevils (Smicronyx fulvus and S. sordidus) in the laboratory, pp. 47-51. In Proceedings, 7th Great Plains Sunflower Insect Workshop. 7-8 April 1992, Fargo, ND.

Charlet, L. D., D. D. Kopp, and C. Y. Oseto. 1987. Sunflowers: their history and associated insect community in the Northern Great Plains. Bull. Entomol. Soc. Am. 33:69-75.

Korman, A. K., and C. Y. Oseto. 1989. Structure of the female reproductive system and maturation of oocyte in Smicronyx fulous (Coleoptera: Curculionidae). Ann. En. tomol. Soc. Am. 82: 94-100. 
Ledercq, P. 1979. Inheritance of the white seed character in sunflower Helianthus annutus. Ann. Amelio. Plant. 29. 107-110.

McMullen, M. P., A. G. Dexter, J. D. Nalewaja, and G. Dahl. 1990. Pesticide use on major crops in North Dakota 1989. North Dakota State University in Cooperation with North Dakota Agricultural Statistics Service, Fargo.

Oseto, C. Y., J. D. Busacca, and L. D. Charlet. 1987. Relationship of sunflower planting dates to damage by Smicronyx fulvus (Coleoptera: Curculionidae) in North Dakota. J. Econ. Entomol. 80: 190-192.

Putt, E. D. 1940. Observation on morphological characters and flowering processes in the sunflower (Helianthus anmuts L.). Sci. Agric. 21: 167-179.
Rana, R. L. 1995. Feeding behavior of adult sunflower seed weevils on sunflower. M.S. thesis, North Dakota State University, Fargo.

Rogers, C. E., and G. L. Kreitner. 1983. Phytomelanin of sunflower achenes: a mechanism for pericarp resistance to abrasion by larvae of the sunflower moth (Lepidoptera: Pyralidae). Environ. Entomol. 12: 277-285.

SAS Institute. 1985. SAS user's guide: statistics, version 5th ed. SAS Institute, Cary, NC.

Schneiter, A. A., and Miller, J. F. 1981. Description of sunflower growth stages. Crop Sci, 21: 901-903.

Received for publication 1 August 1997; accepted 24 February 1998. 